\title{
Relationship between entrepreneurship education and entrepreneurial goal intentions: psychological traits as mediators
}

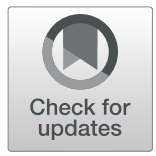

Takawira Munyaradzi Ndofirepi(D)

Correspondence: takandofirepi@
gmail.com
Department of Business Support
Studies, Central University of
Technology, Free State,
Bloemfontein, South Africa

Correspondence: takandofirepi@ gmail.com

Technology, Free State,

Bloemfontein, South Africa

\begin{abstract}
Despite the commonly held view that entrepreneurship education and training nurtures future entrepreneurs, little is known about the mechanism through which this intervention impacts on its intended outcomes. The purpose of this study was to test if selected psychological traits (need for achievement, risk-taking propensity, internal locus of control) mediated the predictive relationship between the perceived effects of entrepreneurship education and entrepreneurial intentions. A crosssectional survey of a sample of 308 vocational education students in Zimbabwe was used for this purpose. The results show that the effects of entrepreneurship education variable had a positive and statistically significant relationship with need for achievement, risk-taking propensity, internal locus of control and entrepreneurial goal intentions. Moreover, need for achievement, risk-taking propensity and internal locus of control accounted for a statistically significant amount of variance in entrepreneurial intentions. However, of the three psychological traits, only need for achievement partially mediated the relationship between the effects of entrepreneurship education and entrepreneurial goal intentions. The outcome has implications on the design and focus of entrepreneurship education programmes.

Keywords: Entrepreneurship education, Entrepreneurial intention, Need for achievement, Risk-taking propensity, Locus of control
\end{abstract}

\section{Introduction}

Governments, development aid agencies and scholars world over are convinced that entrepreneurship is central to economic development, employment creation and improvement of standards of life of people in different communities (Bell, 2015; Karimi, Biemans, Lans, Chizari, \& Mulder, 2014; Klapper, 2004; Malebana \& Swanepoel, 2015; Prakash, Jain, \& Chauhan, 2015). The view is rooted, in part, on the proclamations of seminal scholars like Schumpeter, Schultz, Kirzner and Cantillon which highlight the undertakings of entrepreneurs as powerful drivers of economic activity (Arko-achemfuor, 2014; De Faoite, Henry, Johnston, \& Van Der Sijde, 2003; Moroz \& Hindle, 2012; Solesvik, Westhead, Matlay, \& Parsyak, 2013). If entrepreneurship is integral to socioeconomic transformation, it is then logical to presume that societies which have more individuals with entrepreneurial attributes and, by extension, greater entrepreneurial activity are better placed to progress economically compared to those with lesser

(c) The Author(s). 2020 Open Access This article is distributed under the terms of the Creative Commons Attribution 4.0 International License (http://creativecommons.org/licenses/by/4.0/), which permits unrestricted use, distribution, and reproduction in any medium, provided you give appropriate credit to the original author(s) and the source, provide a link to the Creative Commons license, and indicate if changes were made. 
numbers. It is in this context that calls to intensify entrepreneurship education are ever increasing (Urban, 2009). The idea is to build a substantial stock of creative and innovative human capital. The competencies and attitudes imparted through such education brace young people to confront the ambiguities and difficulties that pervade the contemporary social and economic environments (Owusu-Ansah \& Poku, 2012).

In Zimbabwe, a low-income country with a poorly performing economy, there is a concerted drive by the government through the Ministry of Higher and Tertiary Education to re-orientate the country's higher education system towards equipping students with entrepreneurial skills and attitude as means to curb youth unemployment (Ndofirepi, 2016). This thrust is, in part, anchored on integrating mandatory entrepreneurship education into the various programmes of study offered at the higher education institutions (both degree and non-degree granting) in the country. Besides, in 2018, the Minister of Higher Education and Technology designated six state universities (Midlands State University, Chinhoyi University of Technology, University of Zimbabwe, National University of Science and Technology, National Defence University and Manicaland University of Science and Technology) where business incubators, innovation hubs and science parks were to be established as part of efforts to nurture nascent student entrepreneurs and innovators in line with the country's modernisation and industrialisation vision (Chitumba, 2018). In the national budget statement presented in 2018, a total of US\$380 million was allocated to the Ministry of Higher and Tertiary Education to support research and innovation (Phiri, 2018). In spite of such efforts, it remains a moot point whether entrepreneurship education programmes and the other mentioned interventions serve their purported goal. This conundrum persists in spite of substantial funds being invested in aiding and advancing such causes, albeit based on scanty empirical evidence of its effectiveness (Pittaway \& Cope, 2007). Put differently, ambivalence lingers in terms of what works and to what end. Thus, the research area on the impact of entrepreneurship education in Zimbabwe, like in other places across the world, is emergent and invites further exploration to augment "the evidence base..." (Pittaway \& Cope, 2007: 503). This perspective is shared by Lorz, Mueller, and Volery (2013): 124) who posit that "continuous improvement of entrepreneurship education can only take place if educators understand the implications of entrepreneurship trainings...".

Although a substantial body of literature authenticates the centrality of entrepreneurship education in modelling entrepreneurship-related behaviour among students (Fayolle \& Gailly, 2008; Fayolle, Gailly, \& Lassas-Clerc, 2006; Fretschner \& Weber, 2013; Liñán \& Fayolle, 2015; Liñán, Rodríguez-Cohard, \& Rueda-Cantuche, 2011; von Graevenitz, Harhoff, \& Weber, 2010), it is difficult to ignore other divergent claims which claim that such educational programmes succeed only if individuals with acquiescent entrepreneurial traits take part (Radipere, 2012; Weber, 2013). The following character attributes are commonly linked to entrepreneurship in literature: internal locus of control, propensity to take risk, self-confidence, need for achievement, tolerance of ambiguity and innovativeness (Carland \& Carland, 2000; Dinis, Paço, Ferreira, Raposo, \& Rodrigues, 2013; Ferreira, Raposo, Rodrigues, Dinis, \& Paço, 2012; Frese \& Gielnik, 2014). The association of entrepreneurship with the aforementioned attributes, in a way, props the argument that entrepreneurs possess unique traits (Carland, Hoy, Boulton, \& Carland, 2007; Zhao \& Seibert, 2006). Hence, it is a damning indictment on scholars of entrepreneurship education that only a few studies have sought to validate 
whether, indeed, such entrepreneurial traits are amenable to manipulation through individuals' exposure to entrepreneurship education, and if so, whether there is a knockon effect on behavioural outcomes. Such an oversight denies scholars, educators and policymakers the opportunity to fully understand how entrepreneurship education impacts on individual participants, and this somehow creates a chasm in knowledge. It is this gap which the current study seeks to narrow.

A sample of students who were about to complete a 1-year-long compulsory course in entrepreneurship skills development (ESD) at a vocational education institution in Zimbabwe was used to investigate if selected personal traits (internal locus of control, propensity to take risk and need for achievement) affected the relationship between exposure to entrepreneurship education and entrepreneurial intentions. The integration of personal traits in the study of the said relationship is an acknowledgement of the view that entrepreneurship is "...fundamentally personal" (Frese \& Gielnik, 2014: 414) and "...begins when an individual voluntarily takes a decision to partake" (Karimi et al., 2014). An in-depth understanding of the effects of individual entrepreneurship-related idiosyncrasies on the impact of entrepreneurship education may help educators to identify the fundamental educational needs of students and teachable components. At the same time, educators have the opportunity to get evidence-based guidance on how to design more relevant and effective entrepreneurship education programmes (Radipere, 2012). Even though no specific guiding theory is adopted, the current study rides on intention-based models of entrepreneurship which propose that entrepreneurial intention predates and is a leading indicator of actual behaviour (Ajzen, 1991; Bird, 1988; Franke and Luthje, 2003; Krueger \& Brazeal, 1994). By this logic, external interventions meant to stimulate entrepreneurial activity first influence an individual's intention to engage in the said activity before they impact on actual behaviour. Career choice (Lent, Brown, \& Hackett, 1994) and person-environment fit (Kristof-Brown, Zimmerman, \& Johnson, 2005) theories, which proclaim that individuals pursue careers which suit their outlooks, also provided the foundation of the hypothesised relationships.

The psychological construct, entrepreneurial goal intention, was employed as an impact measure in place of concrete results like, among others, the number of new ventures and jobs created by students because of its strong predictive effect on said outcomes. What is more, entrepreneurial intentions are malleable when exposed to external influences like observing practising entrepreneurs, practical work experience and exposure to relevant education and training (Tkachev \& Kolvereid, 1999). Also, the manifestation of other visible indicators of the impact of entrepreneurship education is delayed and therefore cannot be assessed during and immediately after the students complete the course. In other words, observable influence measures emerge well after the students have completed their courses of study. Hence, a proxy for behaviour (i.e. intention) was adopted. That said, the main research question for the present study was as follows:

Is the relationship between the perceived effects of entrepreneurship education and entrepreneurial intentions mediated by need for achievement, internal locus of control, and risk-taking propensity?

The remainder of the paper is arranged as follows: firstly, a review of relevant literature is undertaken; secondly, the methodological issues are then addressed; thirdly, a summary of study findings is presented; and lastly, the study findings are discussed and relevant conclusions are drawn. 


\section{Literature review}

\section{Overview of entrepreneurship education}

Entrepreneurship education is defined as the development of attitudes, behaviours and capacities that can be applied during an individual's career as an entrepreneur (Wilson, 2009). The notion stretches beyond merely teaching students to start a new business to incorporate other rich learning experiences that are gained from an educational environment. Collectively, these interventions promote "...desire, self-reliance, awareness of opportunity, adaptability to change and tolerance of risk and ambiguity by modifying attitudes, and instilling attributes, intentions, behaviours, knowledge and skills enabling individuals and groups to participate meaningfully in all aspects of life, create something of value, and gain financial independence, or personal satisfaction, or both" (Steenekamp, 2013: 104). Entrepreneurship education is complex as demonstrated by the diversity of its goals and the multiplicity of the ways and contexts in which it is offered. As a result, entrepreneurship-related instructional programmes assume various forms and appellations. For example, Pittaway and Cope (2007) and Pittaway and Edwards (2012) recognise education "for", "about", "through" and "in" entrepreneurship. These forms are explained in turn.

Firstly, education "for" entrepreneurship is designed for individuals who want to start and run a business. Hence the curriculum of such a course emphasises cognate competencies. Secondly, education "in" entrepreneurship stresses the practical side of entrepreneurship. Therefore, participants in such programmes learn by acting and behaving entrepreneurially. Focus is on the ability to move from idea recognition to creating value for customers. Thirdly, education "about" entrepreneurship "follows the academic tradition and poses the question: how can we explain and understand entrepreneurship?" (Hoppe, Westerberg, \& Leffler, 2017: 751). Lastly, education "through" entrepreneurship seeks to equip participants with human competencies that encourage an entrepreneurial approach to the pursuit of societal goals. Thus, participants have to "live" entrepreneurship. In this regard, every member of society, whatever their station in life, is expected to eventually do things entrepreneurially. In line with the preceding classification approach, Liñán (2004) proposed the following types of entrepreneurship education: entrepreneurship awareness education, education for start-up, education for entrepreneurial dynamism and continuing education for entrepreneurship. This taxonomy is closely related to the earlier explained grouping approach notwithstanding the dissimilar terminology used.

Jones and Iredale (2010: 8) assert that the character of contemporary labour markets is such that it inspires "self-employment, starting a business or working for an SME", a situation which has heightened the status of entrepreneurship education. By 2006, approximately 1600 higher education institutions in the USA were involved in entrepreneurial activities and also offered a total of 2200 entrepreneurship-related courses (Pittaway \& Edwards, 2012). This popularity is also noticeable in some sub-Sahara African countries which are struggling economically and cannot create sufficient employment opportunities for their school-leavers. As an illustration, at least 23 South African

public universities offer entrepreneurship-related study courses as part of under- and postgraduate degree programmes (Malebana, 2012). This figure excludes private universities and other non-degree awarding institutions. In Zimbabwe, all state universities and vocational training institutions offer mandatory and optional entrepreneurship 
education and training programmes (Ndofirepi, 2016). Although the stature of entrepreneurship education has grown substantially over the years, critical questions about its effectiveness persist. This situation is worsened by the diversity of entrepreneurship education programmes and their different objectives, target audience and content which, in turn, complicates the effective assessment of the outcome and value of such programmes (Balan \& Metcalfe, 2012), hence the need to for further investigation of the concept.

\section{Entrepreneurial intention}

In the present study, entrepreneurial intention is defined as "a self-acknowledged conviction by a person that they intend to set up a new business venture and consciously plan to do so at some point in the future" (Thompson, 2009: 676). Hence, entrepreneurial intention is a strong sign of entrepreneurial potential. The future referred to in the preceding definition of entrepreneurial intention can be nearby or distant. In addition, such intention does not necessarily have to be realised. Despite its conceptual ambivalence, entrepreneurial intention has been a subject of considerable research over the last three decades (Fayolle \& Liñán, 2014; Liñán \& Fayolle, 2015). Its popularity rode on the prominence of intention-based theories of entrepreneurship like Ajzen's Theory of Planned Behaviour (Ajzen, 1991), Bird's Theory of Implementing Entrepreneurial Ideas (Bird, 1988) and Shapero and Sokol's Theory of Entrepreneurial Event (Shapero \& Sokol, 1982). These theories advance the notion that risky ventures like starting a business are not serendipitous and therefore involved prior preparation by an entrepreneur. Hence, entrepreneurial activity is deliberate and pre-planned. Against this background, many studies in entrepreneurial research have used intention as a proxy for future entrepreneurship behaviour. The usefulness of the entrepreneurial intention as a research variable is perceptible through its widespread application as an indicator of the impact of entrepreneurship education. Likewise, the present study concentrates precisely on the entrepreneurial goal intention variable which lays down what an entrepreneur wishes to accomplish and depicts the extent of effort entrepreneurs are prepared to devote (Bird, 1988).

\section{Psychological traits}

Since it is entrepreneurs who start business ventures (Frese \& Gielnik, 2014), the influence of their underlying motivations and traits cannot be ignored when designing interventions aimed at developing future entrepreneurship. Baum, Frese, Baron and Katz (2006) proposed a reconsideration of the influence of entrepreneurial traits if a better understanding of the entrepreneurship process is to be achieved. The same call was made by Carland, Carland and Stewart (1996) who suggested that it is impossible to understand the dance (read entrepreneurship) without first understanding the dancer (read entrepreneur). Arguably, the argument to reconsider individual traits makes sense in the contemporary environment where entrepreneurship-related educational interventions are increasingly becoming popular and the entrepreneur has become a significant unit in a modern and innovative society. Thus, the need to understand the entrepreneur's psyche is critical if effective educational and training programmes targeted at prospective and practising entrepreneurs are to be designed. 
There are suggestions that the receptiveness of individuals to entrepreneurship support interventions vary depending on psychological traits (Radipere, 2012). People with traits like need for achievement, risk-taking propensity and locus of control have been observed to be more amenable to entrepreneurship education outcomes like increased entrepreneurship intention compared to those who exhibit less of those characteristics (Hansemark, 2003), hence the call to concentrate more resources on developing more tractable individuals. Notwithstanding the preceding arguments, there is counter-evidence, albeit ambivalent, which suggests that individual psychological traits are stable and therefore cannot be altered by exposure to external intervention measures (McCrae \& Costa Jr., 1994; CobbClark \& Schurer, 2012). Other studies have questioned predictive power of personality traits on entrepreneurial intentions (Llewellyn \& Wilson, 2003). However, it is important to note that these findings came from studies which over-concentrated on the big five personality attributes (Openness, Conscientiousness, Extraversion, Agreeableness and Neuroticism), and also did not precisely define the nature of entrepreneurial intentions under-consideration as many past studies were hampered by definitional ambiguities of the concept (Fayolle \& Liñán, 2014; Liñán \& Fayolle, 2015). Recent studies have suggested the following variants of entrepreneurial intention as areas of further research investigation: entrepreneurial goal intention, implementation intention, corporate entrepreneurship intention, social entrepreneurship intention, academic entrepreneurship intention and family entrepreneurship intention. As highlighted earlier on, the variable of interest in the current study is entrepreneurial goal intention.

The appeal of the psychological traits approach in entrepreneurship studies lies in the reality that it provides unique areas of human character which can be investigated in relation to other variables. In the current study, the focus is on the following psychological traits which are commonly associated with entrepreneurship: need for achievement, risk-taking propensity and internal locus of control.

\section{Need for achievement}

Need for achievement refers to "the degree to which one sets and strives to reach goals and the degree to which one works hard and is satisfied with the results of the work" (Gerba 2012: 263). In literature, this concept is intricately associated with entrepreneurship (Awang et al., 2016; Dess, Pinkham, \& Yang, 2011; Dinis, Paço, Ferreira, Raposo, \& Rodrigues, 2013; Ferreira, Raposo, Rodrigues, Dinis, \& Paço, 2012; Gerba, 2012; Zhang, Cai, \& Li, 2014) where it is presented as compatible with human attributes like desire for independence and persistent pursuit of goals. McClelland (1961) argued that individuals with high need for achievement had more likelihood of engaging in energetic and innovative activities, such as entrepreneurship, that required an individual's responsibility for task outcomes when compared to those with lower need for achievement. McClelland went further to assert that the extent of need for achievement among inhabitants of a country influenced the degree of economic development or decline of the country in question. However, Frey (1984: 126) dismissed this suggestion as “...empirically invalid, theoretically inadequate, and offering little value to those interested in promoting economic growth".

Findings from previous research on the influence of need for achievement on entrepreneurship-related variables have been inconsistent and contradictory. On the 
one hand, a number of studies have presented need for achievement as a key determinant of entrepreneurship potential (Zeffane, 2013), entrepreneurship persistence (Wu, Matthews \& Dagher, 2007), decision to be self-employed (Caliendo, Fossen \& Kritikos, 2014), entrepreneurship success (Rauch \& Frese, 2007) and students' entrepreneurship intentions (Crant, 1996; Espiritu-Olmos \& Sastre-Castillo, 2015; Paco, Ferreira, Raposo, Rodrigues \& Dinis, 2015). On the other hand, Hansemark's (2003) longitudinal study of the predictive influence of need for achievement and locus of control on future business start-ups yielded statistically non-significant results. The methodological approach adopted by Hansemark's study, which is its strong point, is different from the ones used in the earlier mentioned studies that reported positive results. This may well explain the different findings observed. Nonetheless, the influence of need for achievement on numerous entrepreneurship-related issues cannot be dismissed. So long as it remains essential that we first understand the person (entrepreneur) in order to fully comprehend entrepreneurship (Baum et al., 2006), there will be some research space for psychological traits like need for achievement in entrepreneurship studies. Such attributes are of particular interest to entrepreneurship educators especially after the salient observation that certain personality attributes predispose learners to entrepreneurship learning and future entrepreneurial behaviour (Radipere, 2012). Since the attribute of high need for achievement can be acquired through culture and education (Wincent \& Ortqvist, 2009; Radu \& Redien-Collot, 2008), it is invaluable to ascertain how an individual's level of need for achievement responds to exposure to entrepreneurship education and if this impacts on entrepreneurial intentions.

\section{Risk-taking propensity}

The concept of risk-taking propensity refers to the degree to which an individual is willing to take chances which involve a possibility of loss (Verheul et al., 2015). It encompasses "...the willingness to commit significant resources to opportunities having a reasonable chance to costly failure" (Alvarez, De Noble, \& Jung, 2006:390). Such propensity is critical in shaping an individual's decision to engage in an entrepreneurial career rather than pursue corporate employment (Antonic et al., 2015). According to Callaghan and Venter (2011) and (Zhang et al., 2014), risk-taking propensity epitomises an entrepreneurial orientation at both firm and individual levels.

The link between risk-taking propensity and entrepreneurship has a strong foundation in literature. For example, early eighteenth century economists like Cantillon and Say associated entrepreneurial with moderate risk-taking (Muffatto, 2015). Also, findings from recent studies buttress the view that taking risk is a core part of entrepreneurship (Dawson \& Henley, 2015; Gerba, 2012; Krueger \& Brazeal, 1994; Verheul et al., 2015). Thus, it is sensible to expect potential and prospective entrepreneurs to have a definite risk-taking propensity since the act of initiating a business venture is regarded as a risk-taking deed (Carland, Carland \& Stewart 1999). Nonetheless, the extent to which this factor distinguishes entrepreneurs from non-entrepreneurs is a matter of dispute (Carland et al., 1999). Some scholars refute the view that risk-taking propensity is an inimitable feature of entrepreneurs (Brockhaus, 1980; Palich \& Bagby, 1995; Busenitz \& Barney, 1997; Fitzsimmons \& Douglas, 2011). In contrast, results from other studies on the relationship between risk-taking propensity and entrepreneurship 
intention have consistently shown a positive and significant between the two variables (Ebrahim \& Schott, 2008; Sánchez, 2013; Sánchez, Carballo, \& Gutiérrez, 2011; Tyagi, 2014). These varied outcomes demonstrate that the link between risk-taking propensity and entrepreneurship is convoluted. That being the case, entrepreneurship educators who are tasked to groom future entrepreneurs and are in search of an effective guiding template may find it invaluable to investigate how the interaction between entrepreneurship education and the risk-taking propensity may influence entrepreneurship intention.

\section{Locus of control}

Locus of control refers to the extent which an individual believes they have power over events in their lives (Rotter, 1966). Psychology literature distinguishes between internal and external locus of control. People with internal loci of control believe in their ability to control their fate and environment (Lefcourt, 1992). Because of this, they are more prone to throw themselves at personal achievement-oriented tasks like entrepreneurial opportunity recognition and pursuit. On the other hand, individuals with external loci defer to external influence (Littunen \& Storhammar, 2000). Put differently, they believe their destiny is outside their control. Several studies have shown that successful entrepreneurs have an internal locus of control compared to ordinary people (Aboal \& Veneri, 2016; Antoncic et al. 2015; Brockhaus, 1982; Chaudary, 2017). Moreover, other studies authenticate the positive relationship between internal locus of control and entrepreneurship intentions (Dinis et al., 2013; Vodă \& Nelu, 2019). The interpretation drawn from these findings is that a high internal locus of control allows entrepreneurs to withstand disappointments and setbacks, and thus persevere. Notwithstanding the overwhelming evidence of the importance of internal locus of control, other studies have failed to separate entrepreneurs and non-entrepreneurs (Brockhaus, 1982). Given a background of these mixed and in some instances contradictory set of findings, the current study also sought to explore if locus of control is subject to the influence of external intervention measures (i.e. entrepreneurship education) and if the aforementioned variable accounted for significant variances in entrepreneurial intentions.

In view of the literature reviewed, the following hypotheses were tested:

H1a Effect of entrepreneurship education predicted the need for achievement of the students.

H1b Effect of entrepreneurship education predicted the risk-taking propensity of the students.

H1c Effect of entrepreneurship education predicted the internal locus of control of the students.

H1d Effect of entrepreneurship education predicted the entrepreneurial intentions of the students.

$\mathrm{H} 2 \mathrm{a}$ Need for achievement predicted the entrepreneurial goal intentions of the students.

$\mathrm{H} 2 \mathrm{~b}$ Risk-taking propensity predicted the entrepreneurial goal intentions of the students.

$\mathrm{H} 2 \mathrm{c}$ Internal locus of control predicted the entrepreneurial goal intentions of the students. 
H3a Need for achievement mediates the relationship between entrepreneurship education and entrepreneurial goal intentions of students.

$\mathrm{H} 3 \mathrm{~b}$ Risk-taking propensity mediates the relationship between entrepreneurship education and entrepreneurial goal intentions of students.

H3c Internal locus of control mediates the relationship between entrepreneurship education and entrepreneurial goal intentions of students.

The hypothesised relationships are depicted in Fig. 1.

\section{Research methodology and design}

This study employed a quantitative research approach based on a cross-sectional survey design. This approach was selected because it allowed for the collection of a large quantity of data from dispersed subjects quickly and at a relatively low cost. Also, findings from quantitative studies are generalizable to the target population, which is in line with the goal of the present study.

\section{Target population and sampling issues}

Respondents were drawn from vocational education students at a Zimbabwean polytechnic who were about to complete a year-long compulsory course in entrepreneurship skills development (ESD). These were recruited from engineering, applied sciences and business fields of study. Entrepreneurship students, not active entrepreneurs, were targeted since the goal of the study was to evaluate entrepreneurial goal intent instead of actual entrepreneurship activity. A sample of 400 students was randomly selected from a total population of 851 enrolled students. Class lists were used as sampling frames. A large sample size was drawn so as to hedge against the effects of possible non-response and drop-outs. Overall, 400 self-completion questionnaires were distributed to respondents. Of this total, 308 completed and usable questionnaires were returned to the researcher and analysed.

\section{Data collection}

Data was collected over a 2-week period in May 2018. The pick-and-drop method was used for this purpose. A research assistant, who was a lecturer at the participating institution, distributed the questionnaires to students during lectures and collected them after completion. This approach explains the high response rate of $77 \%$.

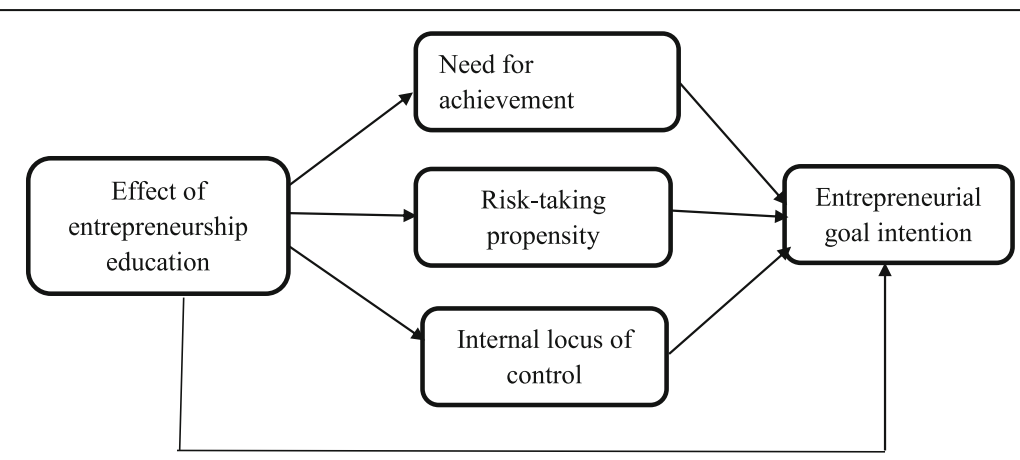

Fig. 1 Conceptual model of hypothesised relationships 


\section{Research instrument}

The questionnaire used in this study comprised close-ended questions covering demographic details of respondents, effect of entrepreneurship education, entrepreneurial goal intention, need for achievement, locus of control and risk-taking propensity. The measuring items for demographic variables were based on a combination of nominal and ordinal scales. On the other hand, those for the predictor, mediator and dependent variables were based on Likert-type scales with response categories ranging from 1 (strongly disagree) to 5 (strongly disagree). The items for measuring effect of entrepreneurship education and need for achievement were adapted from Mwiya (2014), and those representing entrepreneurial goal intention were taken from Liňán and Chen (2009). Lastly, for locus of control and risk-taking propensity, measuring scales from Karimi et al. (2015) were used. The issues of reliability and validity of the measuring scales are addressed in another section.

\section{Profile of respondents}

Of the 308 respondents who completed the questionnaires, 205 were male while 104 were female. In addition, 248 had never been married, 58 were married and only two were divorcees. With regard to respondents' fields of study, 60 were from applied sciences, 64 from business and 184 from engineering. Furthermore, 216 of the total respondents had some entrepreneurship exposure while 92 did not. Lastly, in terms of age, the majority of the respondents, 214, fell in the 21 to 30 age group.

\section{Reliability and validity test results}

An exploratory factor analysis (EFA) of the sample data revealed a five-factor result, which tallies with the latent variables proposed for this study. The Cronbach's alpha and composite reliability coefficient for each variable are presented in Table 1 . Note that one item each was dropped from the original number of measuring items for internal locus of control and risk-taking propensity because of low loading.

As demonstrated in Table 1, the reliability test results for each of the five scales was at least 0.7, indicating acceptable reliability (George \& Mallery, 2003).

Confirmatory factor analysis (CFA) was then applied to evaluate if the posited constructs (entrepreneurial goal intention, effect of entrepreneurship education, need for achievement, internal locus of control and risk-taking propensity) described the data. The results of the CFA model are presented in Table 2. The node diagram for the same analysis is shown in Fig. 2.

The factor loadings of at least 0.6 which were derived for each of the latent variables presented in Table 2 reflect satisfactory convergence validity of the measuring scales

Table 1 Reliability test results

\begin{tabular}{llll}
\hline Scale & No. of items & Alpha coefficient & Composite reliability \\
\hline Entrepreneurship goal intention & 6 & 0.910 & 0.914 \\
Effect of entrepreneurship education & 5 & 0.880 & 0.892 \\
Need for achievement & 5 & 0.840 & 0.876 \\
Internal locus of control & 3 & 0.790 & 0.716 \\
Risk-taking propensity & 3 & 0.770 & 0.749 \\
\hline
\end{tabular}


Table 2 Standardised loadings and significant levels for each parameter in the CFA model

\begin{tabular}{|c|c|c|c|c|}
\hline & & & Estimate & $p$ value \\
\hline ei1 & $\leftarrow$ & $\mathrm{El}$ & 0.653 & - \\
\hline ei2 & $\leftarrow$ & $\mathrm{El}$ & 0.763 & $<0.001$ \\
\hline ei3 & $\leftarrow$ & $\mathrm{El}$ & 0.802 & $<0.001$ \\
\hline ei4 & $\leftarrow$ & $\mathrm{El}$ & 0.905 & $<0.001$ \\
\hline ei5 & $\leftarrow$ & $\mathrm{El}$ & 0.880 & $<0.001$ \\
\hline ei6 & $\leftarrow$ & $\mathrm{El}$ & 0.782 & $<0.001$ \\
\hline pee1 & $\leftarrow$ & PEE & 0.735 & - \\
\hline pee2 & $\leftarrow$ & PEE & 0.834 & $<0.001$ \\
\hline pee3 & $\leftarrow$ & PEE & 0.767 & $<0.001$ \\
\hline pee4 & $\leftarrow$ & PEE & 0.814 & $<0.001$ \\
\hline pee5 & $\leftarrow$ & PEE & 0.795 & $<0.001$ \\
\hline Nach1 & $\leftarrow$ & Nach & 0.610 & - \\
\hline Nach3 & $\leftarrow$ & Nach & 0.807 & $<0.001$ \\
\hline Nach4 & $\leftarrow$ & Nach & 0.690 & $<0.001$ \\
\hline Nach5 & $\leftarrow$ & Nach & 0.601 & $<0.001$ \\
\hline Nach6 & $\leftarrow$ & Nach & 0.528 & $<0.001$ \\
\hline rtp4 & $\leftarrow$ & Rtp & 0.665 & - \\
\hline rtp5 & $\leftarrow$ & Rtp & 0.739 & $<0.001$ \\
\hline rtp6 & $\leftarrow$ & Rtp & 0.712 & $<0.001$ \\
\hline loc1 & $\leftarrow$ & LOC & 0.602 & - \\
\hline loc2 & $\leftarrow$ & LOC & 0.703 & $<0.001$ \\
\hline loc3 & $\leftarrow$ & LOC & 0.720 & $<0.001$ \\
\hline
\end{tabular}

- indicates the statistic was not calculated due to parameter constraint

Ei entrepreneurial goal intention, pee effects of entrepreneurship education, nach need for achievement, rtp risk-taking propensity, loc internal locus of control

(Bagozzi \& Yi, 1988). Discriminant validity was assessed through checking if the square root of average variance extracted (AVE) was greater than the highest shared variance in the model (Fornell \& Larcher (1981: 46). As can be seen in Table 3, the square roots of AVE which are represented by the italicised diagonal digits are greater than shared variance for all the constructs in the model, confirming discriminant validity.

The credibility of the CFA was assessed using a number of goodness-of-fit tests including the chi-squared measure, mean square error of approximation (RMSEA), comparative fit index (CFI), and Tucker-Lewis index (TLI). The outcome of the chi-squared goodness of fit test was statistically significant suggesting that the model did not satisfactorily describe the data. However, the aforementioned test is sensitive to sample size, which causes the test to virtually always reject the null hypothesis and indicate a poor model fit when the sample size is larger than 200 (Hooper, Coughlan, \& Mullen, 2008). The RMSEA index was 0.064, which suggests a good model fit (Hooper et al., 2008). The CFI was 0.920, implying that the model is not misspecified and the fit is acceptable (Hooper et al., 2008). The TLI was less than 0.95, TLI $=0.90$, which is indicative of an acceptable model fit (Hooper et al., 2008).

To assess the possibility of common method bias, Harman's one-factor test was used. Thus, in EFA, all the measuring items in the current study were loaded on one factor. The resultant factor accounted for only $25.977 \%$ of the total variance, confirming the absence of common method bias. 


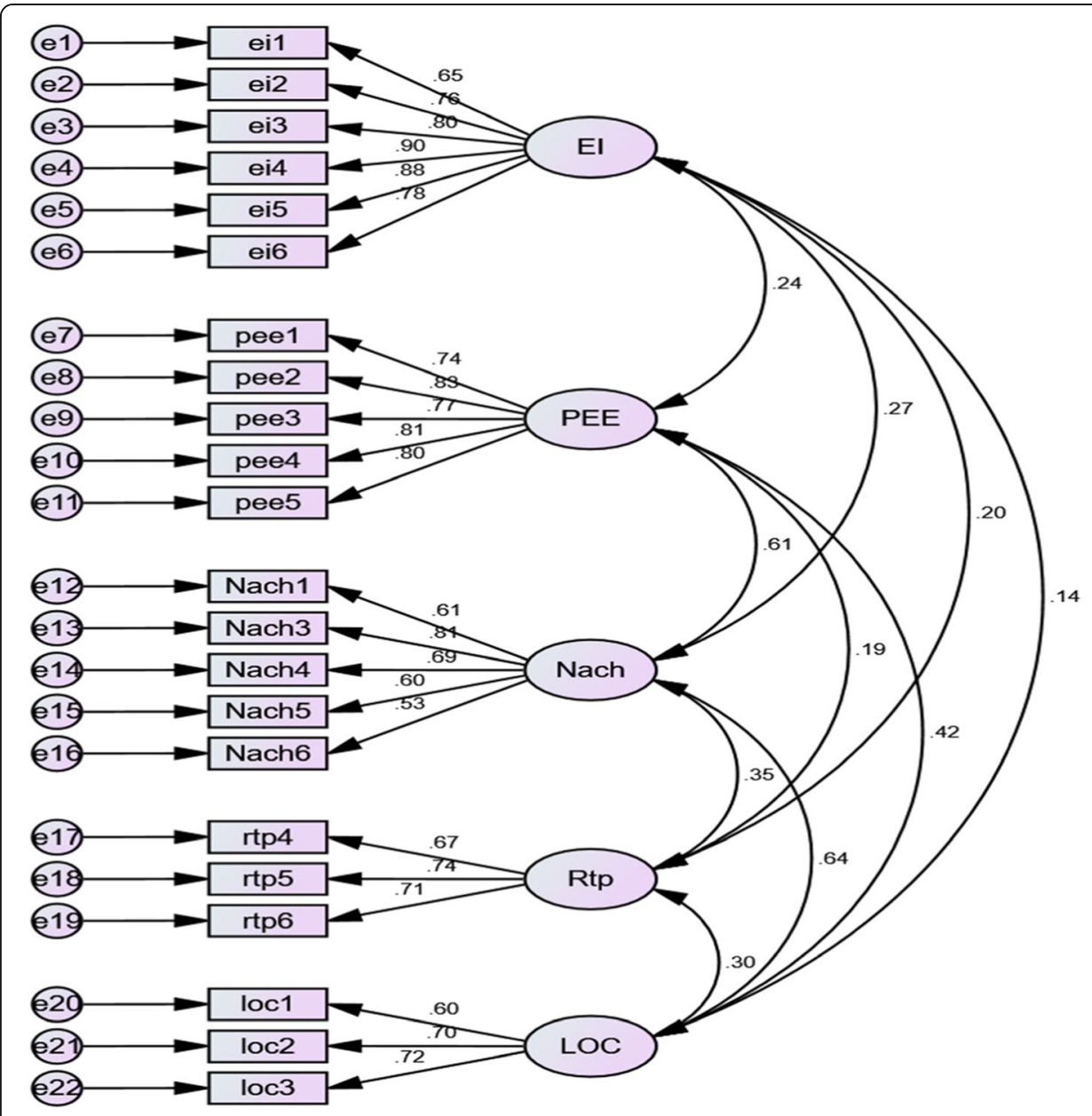

Fig. 2 Node diagram for CFA. Ei, entrepreneurial goal intention; pee effects of entrepreneurship education, nach need for achievement, rtp risk-taking propensity, loc internal locus of control

\section{Control variables}

Results from some studies carried out in the past suggest that demographic factors like gender, age group, marital status, field of study and previous exposure to entrepreneurship can impact on entrepreneurial intentions. As a precautionary measure, the predictive effect of the said variables was tested using a multiple regression analysis model. In this model, gender, age group, marital status, field of study and previous exposure to

Table 3 Model discriminant validity measures

\begin{tabular}{llllllllll}
\hline & CR & AVE & MSV & MaxR(H) & El & PEE & Nach & Rtp & LOC \\
\hline El & 0.914 & 0.643 & 0.071 & 0.931 & 0.802 & & & & \\
PEE & 0.892 & 0.624 & 0.369 & 0.895 & $0.236^{*}$ & 0.790 & & & \\
Nach & 0.786 & 0.428 & 0.411 & 0.812 & $0.266^{* *}$ & $0.607^{* * *}$ & 0.654 & & \\
Rtp & 0.749 & 0.501 & 0.12 & 0.752 & $0.200^{*}$ & 0.194 & $0.347^{* *}$ & 0.708 & \\
LOC & 0.716 & 0.459 & 0.411 & 0.724 & 0.138 & $0.417^{* * *}$ & $0.641^{* * *}$ & $0.305^{*}$ & 0.677
\end{tabular}

Ei entrepreneurial goal intention, pee effects of entrepreneurship education, nach need for achievement, rtp risk-taking propensity, loc internal locus of control, AVE average variance extracted, CR composite reliability, MSV marginal shared variance. ${ }^{*}$ reflects a statistical significance level of $0.1 ;{ }^{* *}$ reflects a statistical significance level of $0.05 ;{ }^{* *}$ reflects a statistical signifiance level of 0.01 
entrepreneurship which are all categorical variables were the predictor variables while entrepreneurial goal intention was the dependent variable. The categorical variables were first dummy-coded to make them appropriate for multiple regression analysis. The results show that there was a collective statistically non-significant effect of the predictors, $\left[F(0,944)=10, p=0.495, R^{2}=0.062\right]$. The individual factors were further examined and indications were that none of them were significant predictors. Hence, they were overlooked in subsequent tests.

\section{Results}

Following the confirmation of the credibility of the specified model, the different hypotheses were tested using the bootstrapping procedure on the basis of 5000 samples and $95 \%$ confidence interval. The path coefficients of the hypothesized relationships and decisions taken are presented in Table 4. These coefficients represent the amount of variance in the dependent variable which was accounted for by the independent variable. From the table, the effect of entrepreneurship education procedure significantly and positively accounted for variances in need for achievement, risk-taking propensity, internal locus of control and entrepreneurial goal intentions. In addition, only need for achievement and risk-taking propensity explained a statistically significant amount of variance in entrepreneurial goal intentions. However, the influence of internal locus of control on entrepreneurial goal intentions was statistically not significant. Chin (1998) suggests that associations between variables with path coefficients greater than 0.2 should be considered strong. Hence, the strongest relationships were observed between effect of entrepreneurial education and need for achievement, need for achievement and entrepreneurial goal intentions and effects of entrepreneurship education and entrepreneurial intentions, respectively.

To assess the mediation effect of need for achievement, risk-taking propensity and internal locus of control, the present study used the Medyad computational tool designed by Coutts, Hayes and Jiang (2019). The tool uses ordinary least squares regression to measure direct and indirect effects in a mediation model. For mediation to be supported, the following conditions be met: (a) the independent variable must be related the dependent variable, (b) the independent variable must be related to the mediator variable, (c) the mediator must be related to the dependent variable while in the presence of the independent variable and (d) the independent variable should no longer be a significant predictor of the dependent variable in the presence of the mediator variable (Baron \& Kenny, 1986).

Table 4 Bootstrapping results

\begin{tabular}{llllll}
\hline Path & Path coefficient & SE & $t$ statistic & $p$ value & Hypothesis decision \\
\hline EEP $\rightarrow$ Nach & 0.405 & 0.060 & 6.721 & 0.000 & Supported \\
EEP $\rightarrow$ Rtp & 0.144 & 0.007 & 2.022 & 0.000 & Supported \\
EEP $\rightarrow$ LoC & 0.181 & 0.041 & 4.437 & 0.000 & Supported \\
EEP $\rightarrow$ El & 0.215 & 0.127 & 1.697 & 0.022 & Supported \\
Nach $\rightarrow$ El & 0.260 & 0.130 & 3.323 & 0.010 & Supported \\
Rtp $\rightarrow$ El & 0.163 & 0.127 & 2.033 & 0.040 & Supported \\
Loc $\rightarrow$ El & 0.130 & 0.212 & 1.612 & 0.109 & Not supported \\
\hline
\end{tabular}

Ei entrepreneurial goal intention, pee effects of entrepreneurship education, nach need for achievement, rtp risk-taking propensity, loc internal locus of control 
The results of the mediation test are summarised in Tables 5, 6 and 7. Both the total and direct effects of entrepreneurship education on entrepreneurial goal intentions were statistically significant as shown by the $p$ values which are less than 0.05 . It should be noted that the total effect of the predictor variable on the predicted variable is greater than the direct effect due to mediation. Further scrutiny of the lower- and upper-level confidence intervals of the three mediated paths presented in Table 7 reveals that only one, that is PEE $\rightarrow \mathrm{Nach} \rightarrow \mathrm{EI}$, did not include a zero value and therefore was statistically significant. The fact that effect of entrepreneurship education predicted entrepreneurial goal intentions before and after need for achievement was included in the regression equation meant that partial mediation was supported. Mediation could not be supported for the other two paths because the condition that the mediator variable must be significantly related to the dependent variable while in the presence of the independent variable could not be met.

\section{Discussion of findings}

The current study proposed and tested a conceptual model which hypothesised that the relationship between students' exposure to entrepreneurship education and entrepreneurial intention is mediated by the following psychological attributes: need for achievement, risk-taking propensity and locus of control. This came against a background where previous studies stress the entrepreneurship education-entrepreneurial intentions relationship without illuminating the mechanism which underlies it. The absence of an incontestable model that explains the process of the aforementioned relationship creates a void in understanding which scholars can further interrogate. Pursuing such a study therefore contributes towards legitimising the generally disregarded research area of entrepreneurship education. According to Fayolle (2015), this side-lining is due to the infancy of the field and lack of robust established models. Further, findings from such a quest are useful to promoters of entrepreneurship education programmes who need to fathom how they can reinforce the key outcomes of such educational offerings.

Hypotheses 1a to 1c proposed that the effect of entrepreneurial education positively explained some variance in need for achievement, risk-taking propensity and locus of control. It is interesting to note that the results confirmed all the three hypotheses. The strongest influence, however, was exerted on need for achievement. These findings mirror certain previous studies which proclaimed the pliability of the said personality traits (Hansemark 1998, 2003; Prakash \& Jain, 2015). Moreover, the fact that entrepreneurial education had the strongest impact on need for achievement confirmed McClelland's (1985) declaration of need for achievement as an acquired need, which educators can possibly entrench in learners through the use of specific educational approaches and techniques. The preceding findings support the conceptual premise that the exposure to entrepreneurial education of individuals at their formative stages in life transforms their psychological outlook, with further repercussion on their career choices. This is

Table 5 Total effects of PEE on El

\begin{tabular}{lllllll}
\hline & Effect & SE & $t$ & $p$ value & LLCl & ULCl \\
\hline El & 0.3381 & 0.1112 & 3.0406 & 0.0028 & 0.1541 & 0.5221 \\
\hline
\end{tabular}


Table 6 Direct effects of PEE on El

\begin{tabular}{lllllll}
\hline & Effect & SE & $t$ & $p$ value & LLCl & ULCl \\
\hline El & 0.2153 & 0.1269 & 1.6976 & 0.0917 & 0.0054 & 0.4253 \\
\hline
\end{tabular}

particularly important for students in a challenging context like Zimbabwe where there are limited formal employment opportunities for school leavers.

In testing hypothesis $1 \mathrm{~d}$, the results revealed that exposure to entrepreneurship education significantly, and in a positive way, accounted for some substantial variance in entrepreneurial goal intentions. The findings corroborate those from studies carried out in non-Western contexts which drew similar conclusions (Dabale \& Masese, 2014; Ekpoh \& Edet, 2011; Ooi \& Nasiru, 2017; Sondari, 2014). The findings affirm the usefulness of entrepreneurial intention as an indicator of the effectiveness of entrepreneurial education programmes. However, due consideration should be given to the fact the observed predictive relationship is conditional to whether the students have prior exposure to entrepreneurship or not (Fayolle \& Gailly 2013) and whether the programme is optional or mandatory (Karimi et al. 2014). Fayolle and Gailly's (2013) study revealed that entrepreneurship education had counter-effects on the entrepreneurial intentions of learners who had substantial previous exposure to entrepreneurship.

Furthermore, the results proved that only need for achievement and risk-taking propensity had a direct and positive effect on changes in entrepreneurial goal intentions, with need for achievement having the greatest impact. These results match those observed in earlier studies (Franke and Luthje, 2003; Lüthje \& Franke, 2004; Remeikiene, Startiene, \& Dumciuviene, 2013; Walter \& Dohse, 2012). However, they contradicted those by Hmieleski and Corbett (2006) who found no such relationships. Contrary to expectations, internal locus of control had a negative but statistically non-significant significant effect on entrepreneurial goal intentions. However, this is consistent with the findings of Dinis et al. (2013) and Ferreira et al. (2012). It is difficult to explain this result, but it might be related to the fact that the high internal locus of control exhibited by the respondents may be due to the optimism and exuberance of youth which might not be connected to business activity.

Surprisingly, of the three proposed mediators, only need for achievement had a statistically significant mediation effect on the effect of entrepreneurship educationentrepreneurial goal intentions relationship. This finding supports previous research into this area which links entrepreneurship education, need for achievement and entrepreneurship intention. Some of these studies suggested that students' exposure to entrepreneurship education reinforced their need for achievement (Hansemark, 1998, 2003) and that a strong need for achievement strongly predicted entrepreneurial intention (Dinis et al., 2013; Ferreira, Raposo, \& Rodrigues, 2012; Uddin \& Bose, 2012).

Table 7 Indirect effects of PEE on El

\begin{tabular}{llllll}
\hline Path & Effect & Boot SE & LLCl & ULCl & \\
\hline PEE $\rightarrow$ Nach $\rightarrow$ El & 0.119 & 0.072 & 0.008 & 0.242 & Supported \\
PEE $\rightarrow$ Rtp $\rightarrow$ El & 0.021 & 0.026 & -0.014 & 0.069 & Not supported \\
PEE $\rightarrow$ LoC $\rightarrow$ El & -0.018 & 0.047 & -0.099 & 0.053 & Not supported \\
\hline
\end{tabular}

Ei entrepreneurial goal intention, pee effects of entrepreneurship education, nach need for achievement, rtp risk-taking propensity, loc internal locus of control, SE standard error, $L L C l$ lower level confidence interval, $L L C I$ upper level confidence 
A possible explanation for this is that the content and values of the entrepreneurship awareness education which the respondents were exposed to reinforced their readiness to pursue discernible accomplishments like start one's own business. This consideration, coupled with the status and prestige enjoyed by successful entrepreneurs in the country, probably persuaded the students to direct the knowledge and skills acquired in entrepreneurship education towards pursuing entrepreneurial careers. However, that only partial mediation was proved means that need for achievement plays limited role on the effect of entrepreneurship education on entrepreneurial goal intentions.

\section{Implications}

Taken together, the study findings have implications for theory and practice. For researchers on the impact of entrepreneurship education, the significance of need for achievement as a mediating factor on the entrepreneurship education-entrepreneurial intentions relationship partially illuminates the process of entrepreneurial goal intentions development. Moreover, the findings underscore the relevance of psychological traits to entrepreneurial research which it had "initially falsely assumed that personality research did not offer it anything useful" (Frese \& Gielnik, 2014: 414). For practitioners, the relevance of psychological traits for the acquisition of entrepreneurial qualities suggests a need to revisit their teaching strategies and design of educational courses. For instance, educators should incorporate and focus more on learning content which feeds and sustains the students need to pursue meaningful life goals as a way to buttress entrepreneurial intentions. Harnessing teaching strategies like the use of role models, mentors, advisors and talks by successful entrepreneurs can also help to achieve the said educational goal. Pedagogical methods should be designed in such a way that they heighten students' awareness of the rewards of pursuing an entrepreneurship as a career.

\section{Limitations and areas for further research}

This study focused exclusively on findings from a sample of students selected from a single vocational institution. This limited spatial focus undercuts the generalisability of the results. Future studies should widen their focus to include students from a number of institutions. Moreover, future studies should also enhance their methodological rigour by using an experimental design and additional situational variables. Lastly, informative insights can also derive by conducting a comparative study of students from engineering and business. The same study can also be done by comparing different groups of gender.

\section{Conclusion}

The findings proved that among the psychological traits studied, only need for achievement mediated, partially, the relationship between entrepreneurship education and entrepreneurial goal intentions. However, the results demonstrated that entrepreneurial education directly affected entrepreneurial goal intentions and the other entrepreneurial traits. Hence, it can be suggested that the exposure of students to entrepreneurship education has ramifications on their psychological development. The study contributes to literature by attempting to shed some light on the mechanism through which 
entrepreneurship education influences entrepreneurial intention. It re-ignites the relevance of some psychological traits to the development entrepreneurship traits. Secondly, the study contributes to entrepreneurial intention literature from a developing world perspective. This has practical implications for educators who have to tailor focus their teaching strategy and course content to reflect the students' need for achievement.

\section{Abbreviations}

AVE: Average variance extracted; CFA: Confirmatory factor analysis; CFI: Comparative fit index; EFA: Exploratory factor analysis; El: Entrepreneurial goal intention; ESD: Entrepreneurial skills development; LLCl: Lower level confidence interval; LOC: Internal locus of control; MSV: Marginal shared variance; NACH: Need for achievement; PEE: Effects of entrepreneurship education,; RMSEA: Mean square error of approximation; RTP: Risk-taking propensity; SE: Standard error; SME: Small and medium enterprises; TLI: Tucker-Lewis index; ULCl: Lower level confidence interval

\section{Acknowledgements}

I wish to thank the participants for participating in the study. I also express my gratitude to the research assistant who helped with the distribution of the questionnaires.

\section{Author's contributions}

The author conceptualised and wrote the article. The author also proof-read, edited and approved the final manuscript.

\section{Author's information}

The author holds a Doctor of Business Administration degree and is a Post-doctoral research fellow in the Department of Business Support Studies at Central University of Technology (South Africa). He is also a full-time lecturer at the Graduate School of Business of the National University of Science and Technology (Zimbabwe) where he teaches Entrepreneurship, Marketing and Entrepreneurship.

\section{Funding}

The study was funded by the author from his own coffers.

\section{Availability data and materials}

The study is based on survey data which was collected using a self-completion questionnaire. The questionnaire and SPSS spreadsheet of the captured data can be availed in reasonable time on request.

\section{Competing interests}

The author declares that he/she has no competing interests.

Received: 18 July 2019 Accepted: 9 January 2020

Published online: 23 January 2020

\section{References}

Aboal, D., \& Veneri, F. (2016). Entrepreneurs in Latin America. Small Business Economics, 46(3), 503-525.

Ajzen, I. (1991). The theory of planned behaviour. Organizational Behavior and Human Decision Processes, 50(2), 179-211.

Alvarez, R. D., DeNoble, A. F., \& Jung, D. (2006). Educational curricula and self-efficacy: Entrepreneurial orientation and new venture intentions among university students in Mexico. International Research in the Business Disciplines, 5(06), 379-403 https://doi.org/10.1016/S1074-7877(06)05019-7.

Antoncic, B., Bratkovic Kregar, T., Singh, G., \& DeNoble, A. F. (2015). The big five personality-entrepreneurship relationship: Evidence from S Slovenia. Journal of Small Business Management, 53(3), 819-841.

Arko-achemfuor, A. (2014). Revisiting entrepreneurship training for adults: Basic education curriculum for employability. Anthropologist, 17(2), 433-440.

Awang, A., Amran, S., Nor, M. N., Ibrahim, I. I., Fazly, M., \& Razali, M. (2016). Individual entrepreneurial orientation impact on entrepreneurial intention: Intervening effect of PBC and subjective norm. Journal of Entrepreneurship, Business and Economics, 4(2), 94-129.

Bagozzi, R. P., \& Yi, Y. (1988). On the evaluation of structural equation models. Journal of the Academy of Marketing Science, 16(1), 74-94.

Balan, P., \& Metcalfe, M. (2012). Identifying teaching methods that engage entrepreneurship students. Education and Training, 54(5), 368-384 https://doi.org/10.1108/00400911211244678.

Baron, R. M., \& Kenny, D. A. (1986). The moderator-mediator variable distinction in social psychological research: Conceptual, strategic, and statistical considerations. Journal of Personality and Social Psychology, 51(6), 1173.

Baum JR, Frese M, Baron R, Katz JA. (2006). Entrepreneurship as an area of psychology: An introduction. In Baum JR, Frese M, Baron R (Eds.), The psychology of entrepreneurship (pp 1-18). New York, NY: Erlbaum.

Bell, R. (2015). Developing the next generation of entrepreneurs: Giving students the opportunity to gain experience and thrive. International Journal of Management Education, 13(1), 37-47 https://doi.org/10.1016/j.ijme.2014.12.002

Bird, B. (1988). Implementing entrepreneurial ideas. The case for intention, 13(3), 442-453.

Brockhaus, R. H. (1982). The psychology of the entrepreneur. Encyclopedia of Entrepreneurship, 39-57.

Brockhaus Sr., R. H. (1980). Risk taking propensity of entrepreneurs. Academy of Management Journal, 23(3), 509-520. 
Busenitz, L. W., \& Barney, J. B. (1997). Differences between entrepreneurs and managers in large organizations: Biases and heuristics in strategic decision-making. Journal of Business Venturing, 12(1), 9-30.

Caliendo, M., Fossen, F., \& Kritikos, A. S. (2014). Personality characteristics and the decisions to become and stay selfemployed. Small Business Economics, 42(4), 787-814.

Callaghan, C., \& Venter, R. (2011). An investigation of the entrepreneurial orientation, context and entrepreneurial performance of inner-city Johannesburg street traders. Southern African Business Review, 15(1), 28-48,

Carland, J. C., \& Carland, J. W. (2000). A new venture creation model. Journal of Business and Entrepreneurship, 12(3), 29-49.

Carland, J. C., Carland, J. W., \& Stewart, W. H. (1996). Seeing what's not there: The enigma of entrepreneurship. Journal of Small Business Strategy, 7(1), 1-20.

Carland, J. C., Carland, J. W., \& Stewart, W. H. (1999). Risk taking propensity: An attribute of entrepreneurship?: A comparative analysis. Letter From The Editor, 5(2), 37.

Carland, W. J., Hoy, F., Boulton, W. R., \& Carland, J. C. (2007). Differentiating entrepreneurs from small business owners: A conceptualization. In Cuervo, Á., Ribeiro, D. and Roig, S. (Eds.) Entrepreneurship: Concept, theory and perspective, Springer, Verlag Berlin Hedeilberg, pp.73-82.

Chaudhary, R. (2017). Demographic factors, personality and entrepreneurial inclination: A study among Indian university students. Education and Training, 59(2), 171-187.

Chin, W. (1998). The partial least squares approach to structural equation modelling", in Marcoulides, G.A. (Ed.) Modern Methods for Business Research, Laurence Erlbaum Associates, NJ, pp. 295-336.

Chitumba, P. (2018). MSU incubation hub a success. Retrieved 15 July 2019, from https:/www.herald.co.zw/msu-incubation-hub-a-success/

Cobb-Clark, D. A., \& Schurer, S. (2012). The stability of big-five personality traits. Economics Letters, 115(1), 11-15.

Coutts, J. J., Hayes, A. F., \& Jiang, T. Easy statistical mediation analysis with distinguishable dyadic data. (2019). Retrieved 15 July 2019, from http://afhayes.com/public/chj2019.pdf

Crant, J.M. (1996). The Proactive Personality Scale as a predictor for entrepreneurial intention. Journal of Small Business Management, 34(3), 42-49.

Dabale, W. P., \& Masese, T. (2014). The influence of entrepreneurship education on beliefs, attitudes and intentions: A crosssectional study of Africa University graduates. European Journal of Business and Social Sciences, 3(9), 1-13.

Dawson, C., \& Henley, A. (2015). Gender, risk, and venture creation intentions. Journal of Small Business Management, 53(2), 501-515 https://doi.org/10.1111/jsbm.12080.

De Faoite, D., Henry, C., Johnston, K., \& Van Der Sijde, P. (2003). Education and training for entrepreneurs: A consideration of initiatives in Ireland and The Netherlands. Education + Training, 45(8/9), 430-438 https://doi.org/ 10.1108/00400910310508829.

Dess, G. G., Pinkham, B. C., \& Yang, H. (2011). Entrepreneurial orientation: Assessing the construct's validity and addressing some of its implications for research in the areas of family business and organizational learning. Entrepreneurship: Theory and Practice, 35(5), 1077-1090 https://doi.org/10.1111/j.1540-6520.2011.00480.x.

Dinis, A., Paço, A., Ferreira, J., Raposo, M., \& Rodrigues, R. G. (2013). Psychological characteristics and entrepreneurial intentions among secondary students. Education + Training, 55(8/9), 1-23 https://doi.org/10.1108/ET-06-2013-0085.

Do Paço, A., Ferreira, J. M., Raposo, M., Rodrigues, R. G., \& Dinis, A. (2015). Entrepreneurial intentions: is education enough? International Entrepreneurship and Management Journal, 11(1), 57-75.

Ebrahim, M., \& Schott, T. (2008). Entrepreneurial intention promoted by perceived capabilities, risk propensity and opportunity awareness: A global study. Retrieved 15 July 2019, from https:/s3.amazonaws.com/academia.edu.documents/5800477/El. pdf?response-content-disposition=inline\%3B\%20filename\%3DEntrepreneurial_Intention_Promoted_by_Pe.pdf\&X-AmzAlgorithm=AWS4-HMAC-SHA256\&X-Amz-Credential=AKIAIWOWYYGZ2Y53UL3A\%2F20190715\%2Fus-east-1\%2Fs3\%2 Faws4_request\&X-Amz-Date $=20190715 T 102230 Z \& X-A m z-E x p i r e s=3600 \& X-A m z-S i g n e d H e a d e r s=h o s t \& X-A m z-S i g n a t u r e=$ e7b1481c19183e01adaefffa53697ae287cd4fa5db8f2be296e7756917e05a7c

Ekpoh, U. I., \& Edet, A. O. (2011). Entrepreneurship education and career intentions of tertiary education students in Akwa Ibom and Cross River States, Nigeria. International Education Studies, 4(1), 172-178.

Espiritu-Olmos, R., \& Sastre-Castillo, M. A. (2015). Personality traits versus work values: Comparing psychological theories on entrepreneurial intention. Journal of Business Research, 68(7), 1595-1598.

Fayolle, A. (2015). Personal views on the future of entrepreneurship education personal views on the future of entrepreneurship education. Entrepreneurship and Regional Development, 25(7-8), 692-701 https://doi.org/10.1080/ 08985626.2013 .821318

Fayolle, A., \& Gailly, B. (2008). From craft to science: Teaching models and learning processes in entrepreneurship education. Journal of European Industrial Training, 32(7), 569-593 https://doi.org/10.1108/03090590810899838.

Fayolle, A., \& Gailly, B. (2013). on Entrepreneurial Attitudes and Intention: Hysteresis and Persistence. The impact of entrepreneurship education on entrepreneurial attitudes and intention: Hysteresis and persistence. Journal of Small Business Management, 53(1), 75-93 https://doi.org/10.1111/jsbm.12065.

Fayolle, A., Gailly, B., \& Lassas-Clerc, N. (2006). Assessing the impact of entrepreneurship education programmes: a new methodology. Journal of European Industrial Training, 30(9), 701-720 https://doi.org/10.1108/03090590610715022.

Fayolle, A., \& Liñán, F. (2014). The future of research on entrepreneurial intentions. Journal of Business Research, 67(5), 663-666 https://doi.org/10.1016/j.jbusres.2013.11.024.

Ferreira, J. J., Raposo, M. L., Rodrigues, R. G., Dinis, A., \& Paço, A. D. (2012). A model of entrepreneurial intention: An application of the psychological and behavioural approaches. Journal of Small Business and Enterprise Development, 19(3), 424-440 https://doi.org/10.1108/14626001211250144.

Fitzsimmons, J. R., \& Douglas, E. J. (2011). Interaction between feasibility and desirability in the formation of entrepreneurial intentions. Journal of Business Venturing, 26(4), 431-440.

Fornell, C., \& Larcker, D. F. (1981). Evaluating structural equation models with unobservable variables and measurement error. Journal of Marketing Research, 18, 39-50.

Franke, N., \& Luthje, C. (2003). The "making" of an entrepreneur: testing a model of entrepreneurial intent among engineering students at MIT. R and D Management, 33(2), 135-147 https://doi.org/10.1111/1467-9310.00288.

Frese, M., \& Gielnik, M. M. (2014). The psychology of entrepreneurship. Annual Review of Organizational Psychology and Organizational Behavior, 1, 413-438 https://doi.org/10.1146/annurev-orgpsych-031413-091326. 
Fretschner, M., \& Weber, S. (2013). Measuring and understanding the effects of entrepreneurial awareness education. Journal of Small Business Management, 51(3), 410-428 https://doi.org/10.1111/jsbm.12019.

Frey, R. S. (1984). Need for achievement, entrepreneurship, and economic growth: a critique of the McClelland thesis. The Social Science Journal., 21(2), 125-134.

George, D., \& Mallery, P. (2003). SPSS for windows step by step: A simple guide and reference. (4th ed.). Boston: Allyn \& Bacon.

Gerba, D. T. (2012). Impact of entrepreneurship education on entrepreneurial intentions of business and engineering students in Ethiopia. African Journal of Economic and Management Studies, 3(2), 258-277 https:/doi.org/10.1108/20400701211265036.

Hansemark, O. C. (1998). The effects of an entrepreneurship programme on need for achievement and locus of control of reinforcement. International Journal of Entrepreneurial Behavior \& Research, 4(1), 28-50.

Hansemark, O. C. (2003). Need for achievement, locus of control and the prediction of business start-ups: A longitudinal study. Journal of Economic Psychology, 24(3), 301-319.

Hmieleski, K. M., \& Corbett, A. C. (2006). Proclivity for improvisation as a predictor of entrepreneurial intentions. Journal of Small Business Management, 44(1), 45-63.

Hooper, D., Coughlan, J., \& Mullen, M. R. (2008). Equation modelling: Guidelines for determining model fit. Electronic Journal of Business Research Methods, 6(1), 53-60.

Hoppe, M., Westerberg, M., \& Leffler, E. (2017). Educational approaches to entrepreneurship in higher education: a view from the Swedish horizon. Education + Training, 59(7/8), 757-767 https://doi.org/10.1108/ET-12-2016-0177.

Jones, B., \& Iredale, N. (2010). Enterprise education as pedagogy. Education and Training, 52(1), 7-19.

Karimi, S., Biemans, H. J. A., Lans, T., Chizari, M., \& Mulder, M. (2014). The impact of entrepreneurship education: A study of Iranian students' entrepreneurial intentions and opportunity identification. Journal of Small Business Management, 54(1), 187-209 https://doi.org/10.1111/jsbm.12137.

Karimi, S., Biemans, H. J. A., Mahdei, K. N., Lans, T., Chizari, M., \& Mulder, M. (2015). Testing the relationship between personality intentions in a developing country. International Journal of Psychology, 1-15. https://doi.org/10.1002/ijop.

Klapper, R. (2004). Government goals and entrepreneurship education - an investigation at a Grande Ecole in France. Education + Training, 46(3), 127-137 https://doi.org/10.1108/00400910410531787.

Kristof-Brown, A. L., Zimmerman, R. D., \& Johnson, E. D. (2005). Consequences of individuals' fit at work: A metaanalysis of person-job, person-organization, person-group, and person-supervisor fit. Personnel Psychology, 58, 281-342.

Krueger, N. F., \& Brazeal, D. V. (1994). Entrepreneurial potential and potential entrepreneurs. Entrepreneurship Theory and Practice, 18(3), 91-104 https://doi.org/10.2139/ssrn.1505244.

Lefcourt, H. M. (1992). Durability and impact of the locus of control construct. Psychological Bulletin, 112(3), 411.

Lent, R. W., Brown, S. D., \& Hackett, G. (1994). Toward a unifying social cognitive theory of career and academic interest, choice, and performance. Journal of Vocational Behavior, 45, 79-122.

Liñán, F. (2004). Intention-based models of entrepreneurship education. Piccolla Impresa/Small Business, 3(1), 11-35.

Liňán, F., \& Chen, Y. W. (2009). Development and cross-cultural application of a specific instrument to measure entrepreneurial intentions. Entrepreneurship: Theory and Practice, 593-617.

Liñán, F., \& Fayolle, A. (2015). A systematic literature review on entrepreneurial intentions: citation, thematic analyses, and research agenda, 907-933. https://doi.org/10.1007/s11365-015-0356-5

Liñán, F., Rodríguez-Cohard, J. C., \& Rueda-Cantuche, J. M. (2011). Factors affecting entrepreneurial intention levels: A role for education. International Entrepreneurship and Management Journal, 7(2), 195-218 https:/doi.org/10.1007/s11365-010-0154-z.

Littunen, H., \& Storhammar, E. (2000). The indicators of locus of control in the small business context. Journal of Enterprising Culture, 8(04), 343-360

Llewellyn, D. J., \& Wilson, K. M. (2003). The controversial role of personality traits in entrepreneurial psychology. Education and Training, 45(6), 341-345.

Lorz, M., Mueller, S., \& Volery, T. (2013). Entrepreneurship education: A systematic review of the methods in impact studies. Journal of enterprising culture, 21(02), 123-151.

Lüthje, C., \& Franke, N. (2004). Entrepreneurial intentions of business students: A benchmarking study. International Journal of Innovation and Technology Management, 1(3), 269-288.

Malebana, M.J. (2012). Entrepreneurial intent of final-year commerce students in the rural provinces of South Africa. Doctoral dissertation, University of South Africa.

Malebana, M. J., \& Swanepoel, E. (2015). Graduate entrepreneurial intentions in the rural provinces of South Africa. Southern African Business Review, 19(1), 89-111.

McClelland, D. (1961). The Achieving Society. New Jersey: Van Nostrand.

McClelland, D. C. (1985). Human Motivation. Glenview, IL: Scott Foresman.

McCrae, R. R., \& Costa Jr., P. T. (1994). The stability of personality: Observations and evaluations. Current Directions in Psychological Science, 3(6), 173-175.

Moroz, P. W., \& Hindle, K. (2012). Entrepreneurship as a process: Toward harmonizing multiple perspectives. Entrepreneurship: Theory and Practice, 36(4), 781-818 https://doi.org/10.1111/j.1540-6520.2011.00452.x.

Muffatto, M. S. M. (2015). Article information: African Journal of Economic and Management Studies, 6(1), 17-54. https://doi. org/http://dx.doi.org/10.1108/AJEMS-10-2012-0064

Mwiya, B.M.K. (2014). The impact of entrepreneurship education on the relationships between institutional and individual factors and entrepreneurial intention of university graduates: Evidence from Zambia. Doctoral dissertation, University of Wolverhampton, United Kingdom, available at https://wlv.openrepository.com/wlv/handle/2436/550224.

Ndofirepi, T. M. (2016). The impact of technological creativity and entrepreneurship education on the entrepreneurship intentions of students at particular tertiary institutions in Zimbabwe and South Africa. Doctoral dissertation, Bloemfontein: Central University of Technology, Free State.

Ooi, Y. K., \& Nasiru, A. (2017). Entrepreneurship education as a catalyst of business start-ups: A study on Malaysian community college students. Asian Social Science, 11(18), 350-364 https://doi.org/10.5539/ass.v11n18p350.

Owusu-Ansah, W., \& Poku, K. (2012). Entrepreneurship education, a panacea to graduate unemployment in Ghana. Journal of Humanities and Social Science, 2(15), 211-220 Retrieved from http://www.jihssnet.com/journalsNNol_2_No_15_August_2012/26.pdf.

Palich, L. E., \& Bagby, D. R. (1995). Using cognitive theory to explain entrepreneurial risk-taking: Challenging conventional wisdom. Journal of Business Venturing, 10(6), 425-438. 
Phiri J (2018). Government outlines university innovation hub strategy. Retrieved 15 July 2019, from https:/www.sundaynews. co.zw/government-outlines-university-innovation-hub-strategy/.

Pittaway, L., \& Cope, J. (2007). Entrepreneurship education: A systematic review of the evidence. International Small Business Journal, 25(5), 479-510 https://doi.org/10.1177/0266242607080656.

Pittaway, L., \& Edwards, C. (2012). Assessment: Examining practice in entrepreneurship education. Education + Training, 54(8/ 9), 778-800 https://doi.org/10.1108/00400911211274882.

Prakash, D., Jain, S., \& Chauhan, K. (2015). Entrepreneurial intensity in relation to presence of entrepreneurship development cell: A study of institutes offering professional courses in national capital region Delhi. International Journal of Management Education, 13(1), 95-105 https://doi.org/10.1016/j.jime.2015.01.004.

Radipere, S. (2012). South African university entrepreneurship education. African Journal of Business Management, 6(44), 11015-11022 https://doi.org/10.5897/AJBM12.410.

Radu, M., \& Redien-Collot, R. (2008). The social representation of entrepreneurs in the French press: Desirable and feasible models? International Small Business Journal, 26(3), 259-298.

Rauch, A., \& Frese, M. (2007). Let's put the person back into entrepreneurship research: A meta-analysis on the relationship between business owners' personality traits, business creation, and success. European Journal of Work and Organizational Psychology, 16(4), 353-385.

Remeikiene, R., Startiene, G., \& Dumciuviene, D. (2013). Explaining entrepreneurial intention of university students: the role of entrepreneurial education. Active Citizenship by Management Knowledge and Learning, 299-307.

Rotter, J. B. 1966. Generalized expectancies for internal versus external control of reinforcement. Psychological Monographs, 8 Whole No. 609.

Sánchez, J. C. (2013). The impact of an entrepreneurship education program on entrepreneurial competencies and intention. Journal of Small Business Management, 51(3), 447-465 https://doi.org/10.1111/jsbm.12025.

Sánchez, J. C., Carballo, T., \& Gutiérrez, A. (2011). The entrepreneur from a cognitive approach. Psicothema, 23(3), 433-438.

Shapero, A., \& Sokol, L. (1982). The sociology of entrepreneurship. Encyclopedia of entrepreneurship. Englewood Cliffs, NJ: Prentice-Hall.

Solesvik, M. Z., Westhead, P., Matlay, H., \& Parsyak, V. N. (2013). Entrepreneurial assets and mindsets benefit from university entrepreneurship education investment, 748-762. https://doi.org/10.1108/ET-06-2013-0075

Sondari, M. C. (2014). Is entrepreneurship education really needed?: Examining the antecedent of entrepreneurial career intention. Procedia - Social and Behavioral Sciences, 115(licies 2013), 44-53. https://doi.org/10.1016/j.sbspro.2014.02.414

Steenekamp, A. G. (2013). An assessment of the impact of entrepreneurship training on the youth in South Africa. Doctoral dissertation, North-West University, South Africa.

Thompson, E. R. (2009). Individual entrepreneurial intent: Construct clarification and development of an internationally reliable metric. Entrepreneurship Theory and Practice, 33(3), 669-694.

Tkachev, A., \& Kolvereid, L. (1999). Self-employment intentions among Russian students. Entrepreneurship and Regional Development, 11(3), 269-280.

Tyagi, V. (2014). Demographic factors and personality traits as determinants of entrepreneurial intention among undergraduate students of Agra City. Retrieved from http://shodh.inflibnet.ac.in/handle/123456789/2159\%5Cn, http:// shodh.inflibnet.ac.in:8080/jspui/bitstream/123456789/2159/1/synopsis.pdf

Uddin, M. R., \& Bose, T. K. (2012). Determinants of entrepreneurial intention of business students in Bangladesh. International Journal of Business and Management, 7(24), p128 https://doi.org/10.5539/ijbm.v7n24p128.

Urban, B. (2009). Entrepreneurship education and entrepreneurial intentions: a prospect for higher education ? Education as Change, (June 2015), 37-41. https://doi.org/10.1080/16823200609487131

Verheul, I., Block, J., Burmeister-Lamp, K., Thurik, R., Tiemeier, H., \& Turturea, R. (2015). ADHD-like behavior and entrepreneurial intentions. Small Business Economics, 45(1), 85-101 https://doi.org/10.1007/s11187-015-9642-4.

Vodă, I. A., \& Nelu, F. (2019). Impact of personality traits and entrepreneurship education on entrepreneurial intentions of business and engineering students. Sustainability, 17(1192), 1-19 https://doi.org/10.3390/su11041192.

von Graevenitz, G., Harhoff, D., \& Weber, R. (2010). The effects of entrepreneurship education. Journal of Economic Behavior and Organization, 76(1), 90-112.

Walter, S. G., \& Dohse, D. (2012). Why mode and regional context matter for entrepreneurship education. Entrepreneurship \& Regional Development: An International Journal. https://doi.org/10.1080/08985626.2012.721009

Weber, R. (2013). Evaluating entrepreneurship education. Doctoral dissertation, Universität München, Munich. https://doi.org/ 10.1007/978-3-8349-3654-7

Wilson, K. (2009). Educating the next wave of entrepreneurs: World Economic Forum Global Education Initiative. Geneva: World Economic Forum

Wincent, J., \& Örtqvist, D. (2009). A comprehensive model of entrepreneur role stress antecedents and consequences. Journal of Business and Psychology, 24(2), 225-243.

Wu, S., Matthews, L., \& Dagher, G. K. (2007). Need for achievement, business goals, and entrepreneurial persistence. Management Research News, 30(12), 928-941.

Zeffane, R. (2013). Need for achievement, personality and entrepreneurial potential: A study of young adults in the United Arab Emirates. Journal of Enterprising Culture, 21(01), 75-105.

Zhang, H., Zhang, T., Cai, H., \& Li, Y. (2014). Proposing and validating a five-dimensional scale for measuring entrepreneurial orientation an empirical study, (71302148). https://doi.org/10.1108/JEEE-03-2014-0004

Zhao, H., \& Seibert, S. E. (2006). The big five personality dimensions and entrepreneurial status: A meta-analytical review. Journal of Applied Psychology, 91(2), 259

\section{Publisher's Note}

Springer Nature remains neutral with regard to jurisdictional claims in published maps and institutional affiliations. 